\title{
Effect of welding parameters on mechanical properties of GTAW of UNS S31803 and UNS S32750 weldments
}

\author{
Prabhu Paulraj* and Rajnish Garg \\ University of Petroleum \& Energy Studies, Dehradun 248007, Uttarakhand, India
}

Received 13 October 2015 / Accepted 13 November 2015

\begin{abstract}
Duplex Stainless Steel (DSS) and Super Duplex Stainless Steel (SDSS) pipes were welded by Gas Tungsten Arc Welding (GTAW) process. The effect of welding parameters such as heat input, cooling rate, shielding/purging gas composition and interpass temperature on tensile strength, hardness and impact toughness were studied. The microstructure analysis revealed presence of intermetallic phases at root region of the weldments. All mechanical properties were improved at lower heat input and high cooling rate due to grain refinement and balanced microstructure [ferrite and austenite]. All weldments exhibited higher strength than base materials. Weld root region was harder than centre and cap region. SDSS is more susceptible to sigma phase formation due to higher alloying elements and weld thermal cycles, which lead to considerable loss of toughness. Higher nitrogen contents in shielding and purging gas resulted strengthening of austenite phase and restriction of dislocations, which ultimately improved mechanical properties. Higher interpass temperature caused reduction in strength and toughness because of grain coarsening and secondary phase precipitation.
\end{abstract}

Key words: DSS, SDSS, Tensile strength, Hardness, Impact toughness, Heat input, Shielding gas, Interpass temperature

\section{Introduction}

Duplex stainless steels (DSS) and Super Duplex Stainless Steels (SDSS) are dual phased steels comprising ferrite and austenite theoretically in equal proportions. They have exceptional mechanical and corrosion properties. Super duplex stainless steels have high chromium and molybdenum content which makes them highly corrosion resistive and higher mechanical strength. DSS and SDSS have wide range of applications in offshore, chemical, paper and pulp industries [1-3].

Welding is a key fabrication technique in applications of duplex and super duplex stainless steels. Welding of DSS and SDSS grades are challenging operation due to their complex microstructure. Improper welding cycles may lead to destroy material properties such as drastic reduction in toughness, strength and corrosion resistance [4].

It is important to obtain balanced microstructure $(50 \%$ Austenite and 50\% Ferrite) after welding. The high arc energy processes (high heat input) such as Submerged Arc Welding (SAW), Gas Metal Arc Welding (GMAW) and Gas Tungsten Arc Welding (GTAW) induce slower cooling rates. This leads

*e-mail: paulrajprabhul@gmail.com to formation of higher amount of austenite as well as wide heat affected zones (HAZ). On the other hand, low arc energy processes like Electron Beam Welding (EBW), Laser Beam Welding (LBW) cause faster cooling and hence very less austenite reformation. The faster cooling may even lead to precipitation of chromium nitrides [5].

The intermetallic phase precipitation is a major issue in DSS/SDSS fabrication. It has been found that toughness is the most sensitive property which gets affected due to secondary phase formation [6]. Hence prolonged exposure between 600 and $1000{ }^{\circ} \mathrm{C}$ is not favourable for DSS/SDSS applications [7].

During welding of duplex stainless steels and super duplex stainless steel, it is important to prevent oxidation of the weldments in order to avoid loss of corrosion resistance. Hence, inert gas such as argon or helium gas purging technique are commonly used to prevent oxidation. Two to five percent nitrogen addition in argon gas [8] improves and assist phase balance.

From the literature review, it was found that there has not been a thorough research work done by considering all the welding parameters of GTAW of DSS and SDSS. The main aim of this work is to characterize mechanical properties of 
Table 1. Base metal chemical composition.

\begin{tabular}{lllllllr}
\hline Material grade & $\mathrm{Cr}$ & $\mathrm{Mo}$ & $\mathrm{Ni}$ & $\mathrm{N}$ & $\mathrm{C}$ & PREN & Remarks \\
\hline UNS S31803 & 22.9 & 3.03 & 7.92 & 0.15 & 0.017 & 35.15 & DSS-Low PREN \\
UNS S31803 & 22.9 & 3.04 & 7.63 & 0.17 & 0.019 & 36.30 & DSS-High PREN \\
UNS S32750 & 25.1 & 3.71 & 8.9 & 0.2 & 0.016 & 40.36 & SDSS-Low PREN \\
UNS S32750 & 25.1 & 3.75 & 8.86 & 0.21 & 0.028 & 41.40 & SDSS-High PREN \\
\hline
\end{tabular}

Table 2. Base material properties.

\begin{tabular}{lccc}
\hline Grade & $\begin{array}{c}\text { Tensile strength } \\
(\mathrm{MPa})\end{array}$ & $\begin{array}{c}\text { Hardness } \\
(\mathrm{VHN})\end{array}$ & $\begin{array}{c}\text { Impact toughness } \\
{[\mathrm{J}] \text { at }-46^{\circ} \mathrm{C}}\end{array}$ \\
\hline DSS-Low PREN & 750 & 255 & 127 \\
DSS-High PREN & 762 & 260 & 109 \\
SDSS-Low PREN & 806 & 301 & 140 \\
SDSS-High PREN & 830 & 310 & 119 \\
\hline
\end{tabular}

the DSS and SDSS materials welded by GTAW technique, which is most commonly used welding process for DSS and SDSS. This paper focuses on effect of welding parameters on mechanical properties of DSS and SDSS weld. We have studied various mechanical properties such as Tensile Strength, Ductility, Impact toughness and Hardness with respect to the welding variables heat input, cooling rate, shielding gas, purging gas and inter-pass temperature.

\section{Experimental details}

\subsection{Research materials}

DSS and SDSS pipes with different PREN were used for this study. Table 1 shows the chemical composition and PREN value of base materials. The pipes were of 2 "diameter, $5.54 \mathrm{~mm}$ thickness (Sch 80) and $150 \mathrm{~mm}$ long. Table 2 shows mechanical properties of base materials. Figure 1 shows typical microstructure of base material comprising dark ferrite phase and bright austenite phase.

The filler metal used for this work was a Sandvik manufactured filler metal of $2 \mathrm{~mm}$ size. The chemical composition of filler metal is given in Table 3.

\subsection{Welding}

DSS and SDSS pipes were welded with Gas Tungsten Arc Welding (GTAW) process. $\mathrm{Ar}+2 \% \mathrm{~N}$ and $\mathrm{Ar}+5 \% \mathrm{~N}$ gas mixture was used as shielding gas and back purging gas (refer Tables 5 and 6). Welding experiments were carried out by varying material grade, welding heat input, cooling rate and by varying shielding gas, purging gas and inter-pass temperature in order to study the effect of welding parameters on mechanical properties of DSS and SDSS welds. The welding parameters ranges are tabulated in Table 4.

During welding experiments, one of the above parameter was varied and other parameters were kept constant. Tables 5 and 6 show experimental details of this section.

After welding, welded pipes were liquid penetrant examined to ensure no surface defects and followed by radiographic

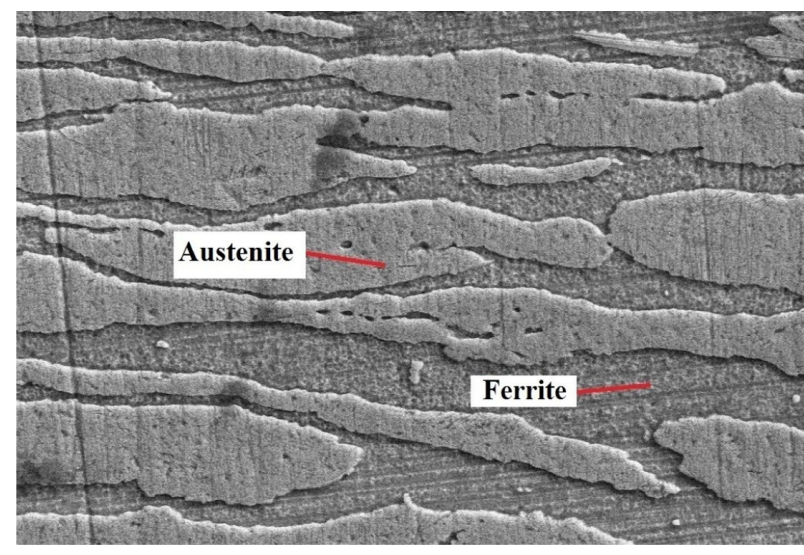

Figure 1. Typical base material microstructure.

examined to ensure no defects though out the thickness. Subsequently, mechanical test samples were prepared as per ASME Sec-IX.

\subsection{Metallography}

Metallographic studies were performed using optical microscopy. First the specimen were polished on emery sheets up to 1200 grit fineness. Then cloth polishing was done using alumina powder of $0.05 \mu \mathrm{m}$ size. The weldments etched with $20 \% \mathrm{NaOH}$ solution and they were examined under optical microscopes. The ferrite content measurements were done by point count method in accordance with E562 standard.

\subsection{Mechanical testing}

After successful completion of welding, the specimen were subjected to mechanical testing. The weldments were characterised with tensile test, hardness test and impact test. For tensile test, ASME IX standard followed. The material thickness and width were $5.30 \mathrm{~mm}$ and $13.20 \mathrm{~mm}$ respectively. Three sets of tests were performed and average value was taken to this study. Fractured surfaces were examined with SEM images. Charpy V-notch impact tests were performed on a pendulum type impact tester as per ASTM A370 standard. The specimen dimensions used for impact tests was $5 \times 10 \times 55 \mathrm{~mm}$. All the impact tests were carried out at $-46{ }^{\circ} \mathrm{C}$.

Hardness measurements were taken on transverse section of weldments where hardness values were measured at weld metal, HAZ and base metal. Also hardness was measured along thickness of weldments. The ASTM E92 standard was followed with $10 \mathrm{~kg}$ of test load. 
Table 3. Filler metal chemical composition.

\begin{tabular}{|c|c|c|c|c|c|c|c|c|c|c|}
\hline Base metal & Filler grade & $\mathrm{C}$ & $\mathrm{Si}$ & $\mathrm{Mn}$ & $\mathrm{P}$ & $\mathrm{S}$ & $\mathrm{Cr}$ & $\mathrm{Ni}$ & Mo & $\mathrm{N}$ \\
\hline DSS & $22.8 .3 . \mathrm{L}$ & $\leq 0.02$ & 0.5 & 1.6 & $\leq 0.02$ & $\leq 0.015$ & 23 & 9 & 3.2 & $\overline{0.16}$ \\
\hline SDSS & 25.10.4.L & $\leq 0.02$ & 0.3 & 0.4 & $\leq 0.02$ & $\leq 0.015$ & 25 & 9.5 & 4 & 0.25 \\
\hline
\end{tabular}

Table 4. Welding specifications.

\begin{tabular}{lc}
\hline Welding position & $5 \mathrm{G}$ \\
\hline Groove design & Single V groove $65-75^{\circ}$ groove angle, \\
& $1-1.5 \mathrm{~mm}$ root face, \\
& $2.5-4 \mathrm{~mm}$ root gap \\
Welding current $(\mathrm{A})$ & $80-150$ \\
Arc voltage $(\mathrm{V})$ & $10-12$ \\
Welding speed $(\mathrm{mm} / \mathrm{min})$ & $40-80$ \\
Number of weld layers & $4-5$ \\
Inter pass temperature $\left({ }^{\circ} \mathrm{C}\right)$ & $100-140$ \\
Gas flow rate $(\mathrm{L} / \mathrm{min})$ & $13-18$ \\
\hline
\end{tabular}

Table 5. Welding parameters to study effect of shielding/purging gas and interpass temperature.

\begin{tabular}{lccccc}
\hline Specimen & PREN & $\begin{array}{c}\text { Heat } \\
\text { input } \\
(\mathrm{kJ} / \mathrm{mm})\end{array}$ & $\begin{array}{c}\text { Shielding } \\
\text { gas }\end{array}$ & $\begin{array}{c}\text { Purging } \\
\text { gas }\end{array}$ & $\begin{array}{c}\text { Interpass } \\
\text { temperature } \\
\left({ }^{\circ} \mathrm{C}\right)\end{array}$ \\
\hline 1 & 35.55 & 1.05 & $\mathrm{Ar}+2 \% \mathrm{~N}$ & $\mathrm{Ar}+2 \% \mathrm{~N}$ & 120 \\
2 & 35.55 & 1.05 & $\mathrm{Ar}+5 \% \mathrm{~N}$ & $\mathrm{Ar}+2 \% \mathrm{~N}$ & 120 \\
3 & 35.55 & 1.05 & $\mathrm{Ar}+2 \% \mathrm{~N}$ & $\mathrm{Ar}+5 \% \mathrm{~N}$ & 120 \\
4 & 35.55 & 1.05 & $\mathrm{Ar}+2 \% \mathrm{~N}$ & $\mathrm{Ar}+2 \% \mathrm{~N}$ & 160 \\
\hline
\end{tabular}

Table 6. Welding parameters to study effect of shielding/purging gas and interpass temperature for SDSS weldments.

\begin{tabular}{lccccc}
\hline Exp. no. PREN & $\begin{array}{c}\text { Heat } \\
\text { input } \\
(\mathrm{kJ} / \mathrm{mm})\end{array}$ & $\begin{array}{c}\text { Shielding } \\
\text { gas }\end{array}$ & $\begin{array}{c}\text { Purging } \\
\text { gas }\end{array}$ & $\begin{array}{c}\text { Interpass } \\
\text { temperature } \\
\left({ }^{\circ} \mathrm{C}\right)\end{array}$ \\
\hline 1 & 41.4 & 1.05 & $\mathrm{Ar}+2 \% \mathrm{~N}$ & $\mathrm{Ar}+2 \% \mathrm{~N}$ & 120 \\
2 & 41.4 & 1.05 & $\mathrm{Ar}+5 \% \mathrm{~N}$ & $\mathrm{Ar}+2 \% \mathrm{~N}$ & 120 \\
3 & 41.4 & 1.05 & $\mathrm{Ar}+2 \% \mathrm{~N}$ & $\mathrm{Ar}+5 \% \mathrm{~N}$ & 120 \\
4 & 41.4 & 1.05 & $\mathrm{Ar}+2 \% \mathrm{~N}$ & $\mathrm{Ar}+2 \% \mathrm{~N}$ & 160 \\
\hline
\end{tabular}

\section{Results and discussion}

The results of mechanical tests for first part of this work (i.e. to study the effect of heat input on weldments) are tabulated in Tables 7 and 8. The Experiment no. 1-4 were done on low PREN DSS/SDSS grades and Experiment no. 5-8 are done on high PREN DSS/SDSS grades.

Effect of shielding/purging gas composition and interpass temperature on mechanical properties on DSS and SDSS welds are shown in Tables 9 and 10.

\subsection{Microstructure of weldments}

A typical microstructure of weldments is shown in Figures 2 and 3 . The weld region microstructure differed across the thickness of the pipe. It can be divided into cap and root
Table 7. Results of mechanical tests for DSS joints.

\begin{tabular}{lccccc}
\hline $\begin{array}{l}\text { Exp. } \\
\text { no. }\end{array}$ & Specimen & $\begin{array}{c}\text { Heat } \\
\text { input } \\
(\mathrm{kJ} / \mathrm{mm})\end{array}$ & $\begin{array}{c}\text { Tensile } \\
\text { strength } \\
(\mathrm{MPa})\end{array}$ & $\begin{array}{c}\text { Impact } \\
\text { toughness at } \\
-46{ }^{\circ} \mathrm{C}(\mathrm{J})\end{array}$ & $\begin{array}{c}\text { Hardness } \\
(\mathrm{VHN})\end{array}$ \\
\hline 1 & DSS- Low & 1.05 & 795 & 168 & 266 \\
2 & PREN & 1.10 & 780 & 140 & 264 \\
3 & & 1.15 & 767 & 123 & 259 \\
4 & & 1.20 & 755 & 85 & 255 \\
5 & DSS- High & 1.0 & 805 & 115 & 275 \\
6 & PREN & 1.05 & 802 & 104 & 270 \\
7 & & 1.1 & 785 & 97 & 266 \\
8 & & 1.15 & 777 & 94 & 261 \\
\hline
\end{tabular}

Table 8. Results of mechanical tests for SDSS joints.

\begin{tabular}{lccccc}
\hline $\begin{array}{l}\text { Exp. } \\
\text { no. }\end{array}$ & Specimen & $\begin{array}{c}\text { Heat input } \\
(\mathrm{kJ} / \mathrm{mm})\end{array}$ & $\begin{array}{c}\text { Tensile } \\
\text { strength } \\
(\mathrm{MPa})\end{array}$ & $\begin{array}{c}\text { Impact } \\
\text { toughness at } \\
-46{ }^{\circ} \mathrm{C}(\mathrm{J})\end{array}$ & $\begin{array}{c}\text { Hardness } \\
(\mathrm{VHN})\end{array}$ \\
\hline 1 & SDSS- Low & 0.95 & 862 & 140 & 319 \\
2 & PREN & 1.05 & 844 & 130 & 312 \\
3 & & 1.15 & 827 & 126 & 298 \\
4 & & 1.25 & 805 & 107 & 288 \\
5 & SDSS- & 0.75 & 896 & 90 & 326 \\
6 & High & 1.0 & 880 & 81 & 320 \\
7 & PREN & 1.1 & 855 & 72 & 315 \\
8 & & 1.2 & 835 & 64 & 302 \\
\hline
\end{tabular}

Table 9. Results of mechanical tests by varying shielding/purging gas and interpass temperature for DSS.

\begin{tabular}{lcccc}
\hline $\begin{array}{l}\text { Experiment } \\
\text { No. }\end{array}$ & $\begin{array}{c}\text { Heat input } \\
(\mathrm{kJ} / \mathrm{mm})\end{array}$ & $\begin{array}{c}\text { Tensile } \\
\text { strength } \\
(\mathrm{MPa})\end{array}$ & $\begin{array}{c}\text { Hardness } \\
(\mathrm{VHN})\end{array}$ & $\begin{array}{c}\text { Impact } \\
\text { toughness at } \\
-46{ }^{\circ} \mathrm{C}(\mathrm{J})\end{array}$ \\
\hline 1 & 1.05 & 805 & 275 & 112 \\
2 & 1.05 & 820 & 281 & 131 \\
3 & 1.05 & 818 & 277 & 135 \\
4 & 1.05 & 784 & 290 & 86 \\
\hline
\end{tabular}

Table 10. Results of mechanical tests by varying shielding/purging gas and interpass temperature for SDSS.

\begin{tabular}{lcccc}
\hline $\begin{array}{l}\text { Experiment } \\
\text { No. }\end{array}$ & $\begin{array}{c}\text { Heat } \\
\text { input } \\
(\mathrm{kJ} / \mathrm{mm})\end{array}$ & $\begin{array}{c}\text { Tensile } \\
\text { strength } \\
(\mathrm{MPa})\end{array}$ & $\begin{array}{c}\text { Hardness } \\
(\mathrm{VHN})\end{array}$ & $\begin{array}{c}\text { Impact } \\
\text { toughness at } \\
-46{ }^{\circ} \mathrm{C}(\mathrm{J})\end{array}$ \\
\hline 1 & 1.05 & 880 & 312 & 130 \\
2 & 1.05 & 895 & 322 & 146 \\
3 & 1.05 & 888 & 317 & 143 \\
4 & 1.05 & 868 & 319 & 104 \\
\hline
\end{tabular}

regions. Due to constant reheating effect in the root region, secondary austenite was found to be precipitated at the root region. The microstructure at cap region cosist of 


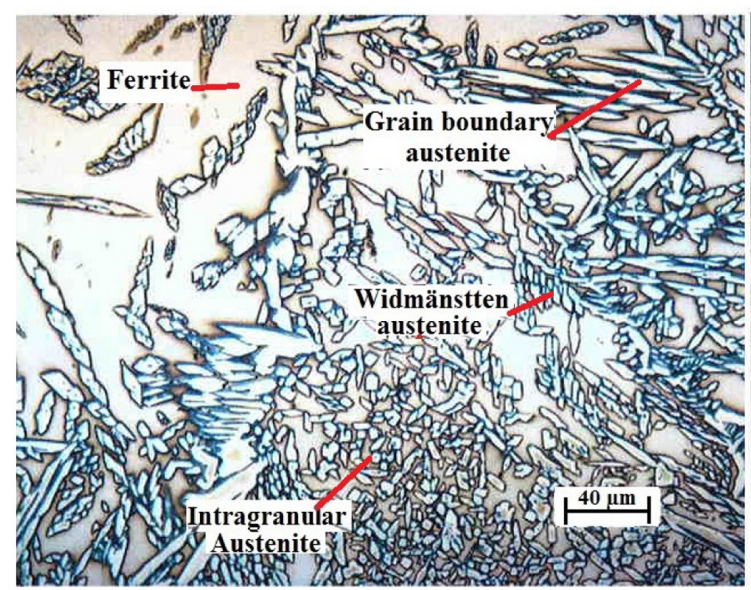

(a)

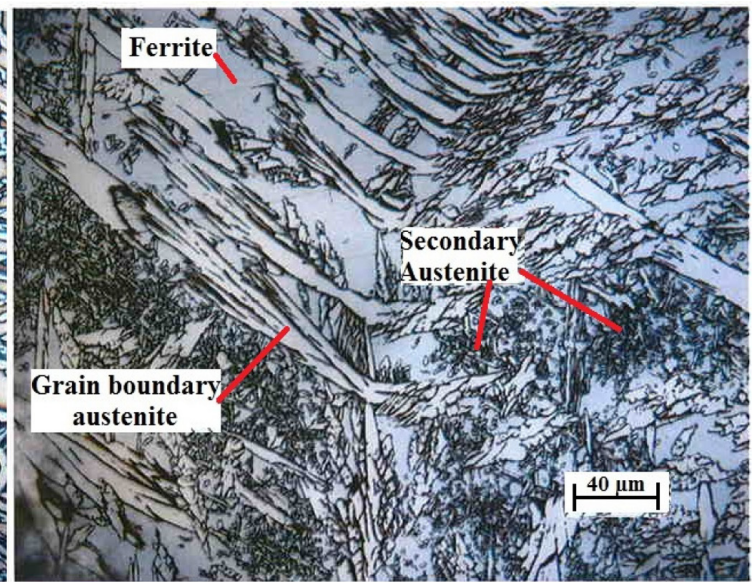

(b)

Figure 2. (a) Microstructure of weld cap region, (b) microstructure of weld root region.

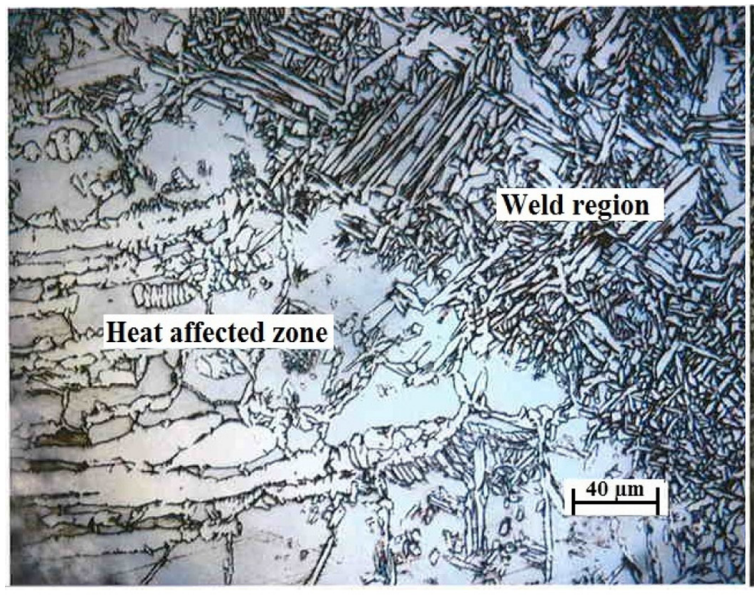

(a)

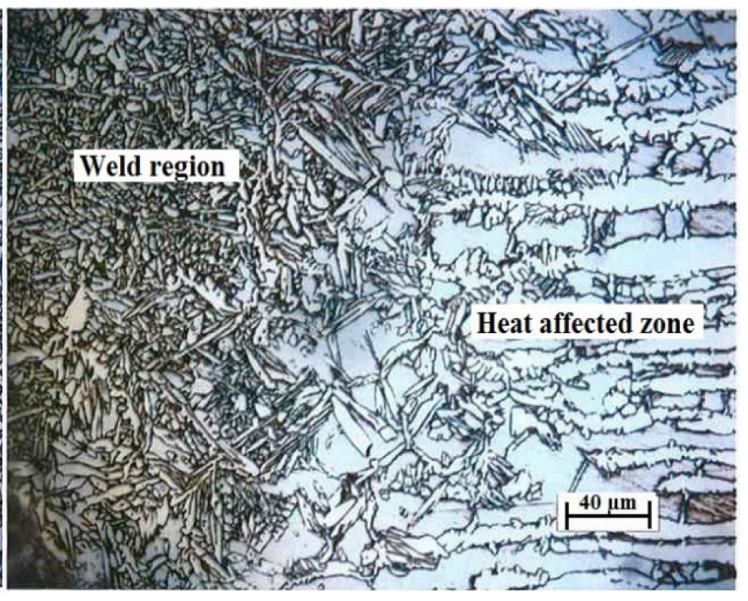

(b)

Figure 3. Microstructure of Heat affected zone (a) left hand side, (b) right hand side.

Table 11. Ferrite content (\%) measurements DSS weldments with variable heat input.

\begin{tabular}{lccccc}
\hline Specimen & $\begin{array}{c}\text { Heat input } \\
(\mathrm{kJ} / \mathrm{mm})\end{array}$ & Cap & Root & HAZ-cap & HAZ-root \\
\hline DSS- Low PREN & 1.05 & 54 & 38 & 54 & 48 \\
& 1.10 & 46 & 43 & 52 & 43 \\
& 1.15 & 39 & 36 & 55 & 51 \\
DSS- High PREN & 1.20 & 35 & 34 & 50 & 48 \\
& 1.05 & 55 & 35 & 65 & 60 \\
& 1.0 & 45 & 39 & 51 & 50 \\
& 1.1 & 44 & 42 & 50 & 44 \\
& 1.15 & 38 & 35 & 44 & 43 \\
\hline
\end{tabular}

intergranualar, intragranualar and widmanstten austenite structure formed inside ferrite matrix. There was no evidence of secondary phases in weld cap region. It was also observed that ferrite content in weld cap was more than that of weld root region.

In this study, we noticed HAZ comprised of coarse grains of ferrite and austenite. There were no intermetallic phase formation observed in HAZ region and no evidence of chromium nitrides formation in the weldments.

The ferrite content has been measured using point count method. The test results are tabulated in Tables 11 and 12. It was observed that at higher heat input, lesser ferrite was formed due slower cooling rates which indirectly facilitated higher austenite formation (Tables 13 and 14).

\subsection{Tensile strength tests}

Tables 6 and 7 show tensile test results. All the samples exhibited excellent tensile strength. All the weldments had higher strength value than the base metal. Hence the welds were fractured outside the weld region. The weld strength was found to be more $5-10 \%$ as compared to base material. This is because of higher tensile properties of the filler wire. The highest strength obtained was $805 \mathrm{MPa}$ and $896 \mathrm{MPa}$ for DSS and SDSS respectively. The fractography is shown in Figure 4 which indicates ductile mode of fracture where micro/macro void coalescence (i.e. dimples) are visible. 
Table 12. Ferrite content (\%) measurements SDSS weldments with variable heat input.

\begin{tabular}{lccccc}
\hline Specimen & $\begin{array}{c}\text { Heat input } \\
(\mathrm{kJ} / \mathrm{mm})\end{array}$ & Cap & Root & HAZ-cap & HAZ-root \\
\hline SDSS- Low PREN & 0.95 & 56 & 39 & 42 & 39 \\
& 1.05 & 48 & 46 & 49 & 48 \\
& 1.15 & 48 & 43 & 49 & 47 \\
SDSS- High PREN & 1.25 & 46 & 38 & 48 & 45 \\
& 0.75 & 64 & 46 & 61 & 56 \\
& 1.0 & 58 & 49 & 56 & 55 \\
& 1.1 & 55 & 51 & 51 & 48 \\
& 1.2 & 52 & 45 & 48 & 43 \\
\hline
\end{tabular}

Table 13. Ferrite content measurements (study effect of shielding/ purging gas and interpass temperature for DSS weldments).

\begin{tabular}{lcccc}
\hline Exp. no. & Cap & Root & HAZ-cap & HAZ-root \\
\hline 1 & 54 & 38 & 54 & 48 \\
2 & 51 & 37 & 50 & 46 \\
3 & 49 & 34 & 48 & 46 \\
4 & 68 & 46 & 61 & 43 \\
\hline
\end{tabular}

Table 14. Ferrite content measurements (study effect of shielding/ purging gas and interpass temperature for SDSS weldments).

\begin{tabular}{lcccc}
\hline Exp. no. & Cap & Root & HAZ-cap & HAZ-root \\
\hline 1 & 56 & 39 & 42 & 39 \\
2 & 51 & 37 & 41 & 37 \\
3 & 49 & 34 & 41 & 39 \\
4 & 70 & 46 & 64 & 44 \\
\hline
\end{tabular}

It was observed that low heat input gives higher tensile strength as compared to high heat inputs. This is due to higher cooling rates induced in low heat input welding which results in finer grains and more ferrite formation. Improved strength of the weldments is due to higher ferrite formation and fine grain

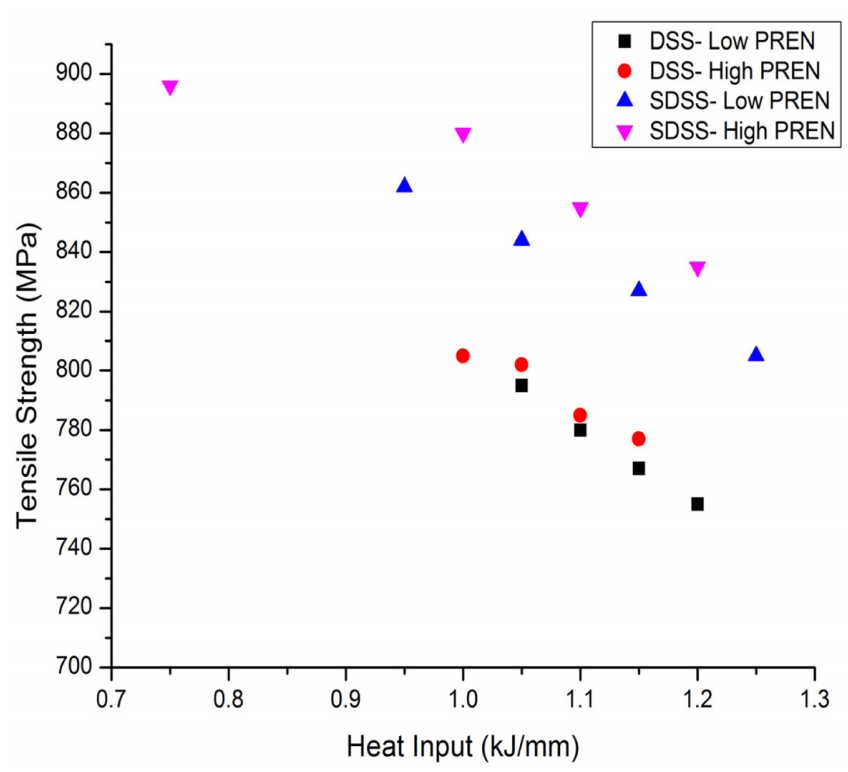

Figure 5. Variation of tensile strength with heat input.

size [1]. The graph showing variation of tensile strength with heat input is shown in Figure 5.

The effect of shielding gas and purging gas on mechanical properties was analysed as shown in Tables 9 and 10. For both DSS and SDSS welds, it was found that increase in Nitrogen content in shielding and purging gas had a positive effect on mechanical properties of weldments. Nitrogen being an austenite stabilizer, affects the weld microstructure. It dissolves mostly in austenite and gives solution strengthening effect especially to austenite phase. Hence there was a slight increase in strength of the weldments [9]. On the other hand increase in interpass temperature results in decrease in tensile strength. This is due to high temperature which leads to coarsening of grains and loss of phase balance. Possibilities for intermetallic phases formation due to slow cooling could have reduced tensile strength of the materials.

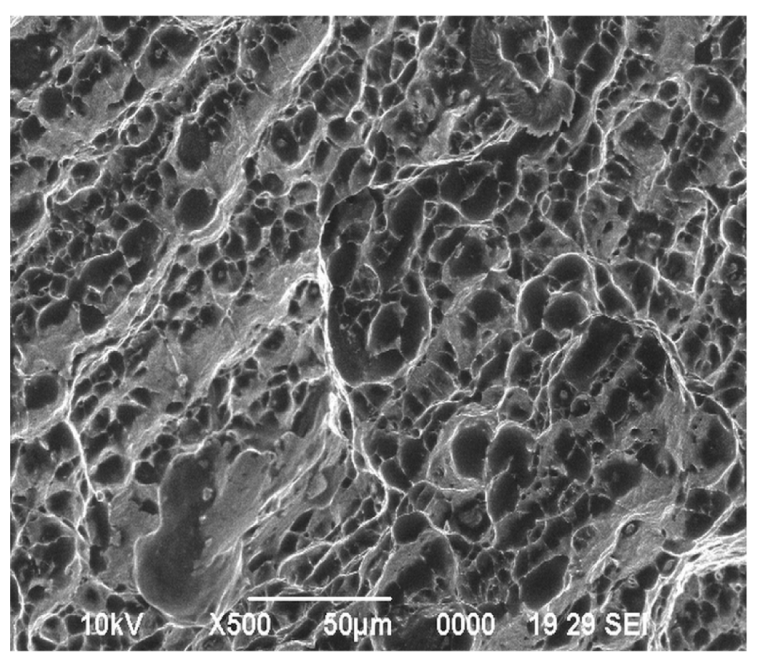

(a)

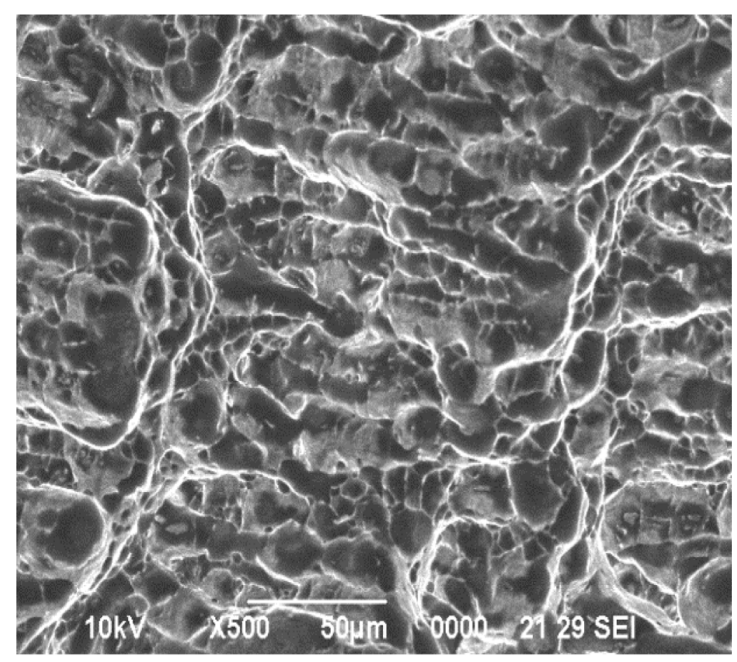

(b)

Figure 4. SEM images of fractured surfaces in tensile tests (a) DSS, (b) SDSS. 


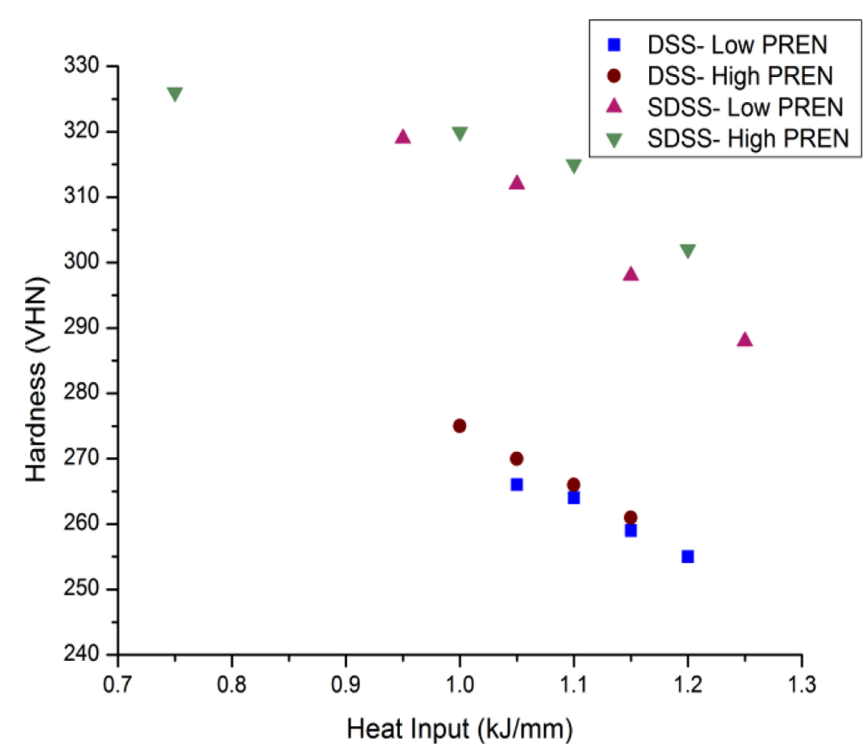

Figure 6. Variation of hardness with heat input.

\subsection{Hardness}

The results of hardness measurements taken on Vickers hardness machine are shown in Tables 7 and 8. The hardness value of weld metals was found to be higher than the base material. This is due to higher alloying element filler wire and repeated heating and cooling cycle. Effect of heat input on hardness value was analysed and developed scattered diagram as shown in Figure 6. It was observed that with low heat input (i.e. higher cooling rate), high hardness values were noted due to grain refinement.

The hardness values were analysed across the transverse section of the weldments. It was noted that weld region exhibited higher hardness than HAZ due to higher alloying element filler wire and grains refinement. Figure 7 shows hardness variation along the length the joint.

The hardness values were also measured along a vertical line of weld region i.e. weld cap, weld centre, weld root. There was a difference between hardness values at each region. A typical distribution of hardness along the thickness of the weldments is shown in Figure 8. The weld root region exhibited higher hardness values due to continuous repeated heating and cooling cycles and grain refinement. Another possibility is the presence of brittle intermetallic phases could have increased hardness value at weld root [10]. Weld centre had lower hardness than weld cap region. The weld cap hardness was slightly lower than root but higher than weld centre because of faster cooling rate on the cap surface than inside the weld. From this, we can conclude that temper bead technique will minimize the hardness value at the surface if there is an application limitation for surface hardness value.

There was a slight increase in hardness of DSS and SDSS weldments when high nitrogen content is used in shielding and purging gas owing to hardening of austenite phase. It was observed that an increase in inter-pass temperature had increased hardness value of the weldments and HAZ. This could be because of increase in inter-pass temperature may
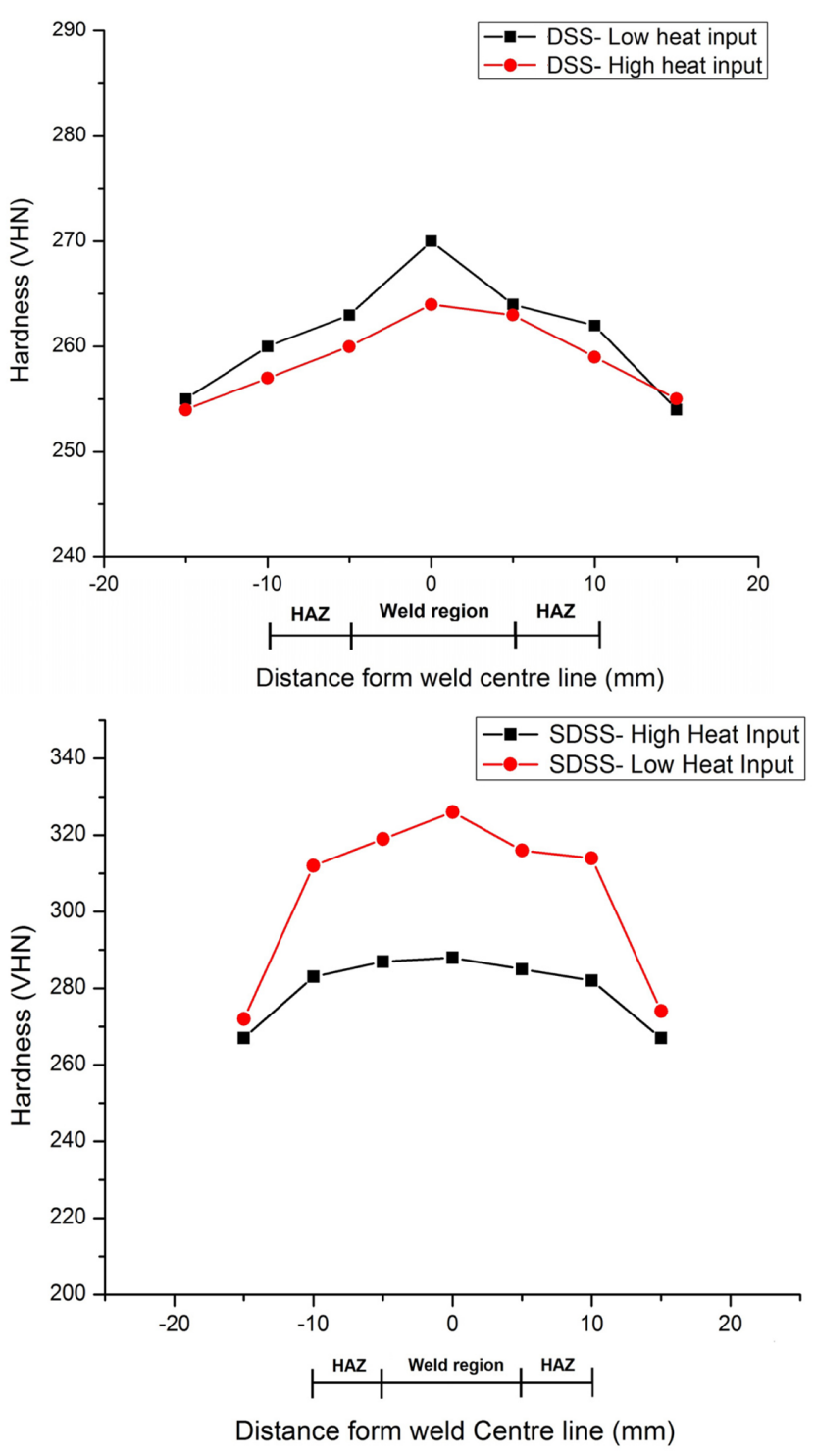

Figure 7. Hardness measurements along transverse section (a) DSS weldments, (b) SDSS weldments.

lead for formation of hard and brittle intermetallic phases due to slow cooling.

\subsection{Impact toughness}

Impact toughness of duplex stainless steel welds depends on many factors such as grain size, austenite formation, secondary austenite and intermetallic phase precipitation. The effect of heat input on impact toughness of weld metal is shown in Figure 9. It was observed that high heat input reduced toughness value of the joints. This is because of formation of coarse grains due to slow cooling because of high heat input. Although formation of austenite was facilitated by high heat input, precipitation of intermetallic phases (i.e. sigma phase and secondary austenite) is unavoidable at higher heat input which may leads to reduce impact toughness properties of the weld. This observation is in line with the literature $[6,7]$. 


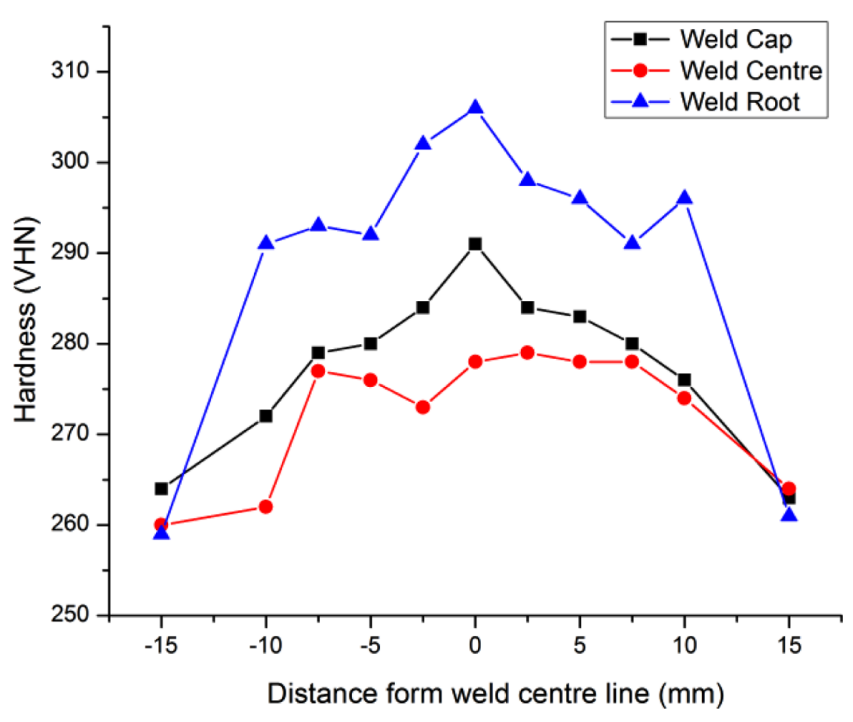

Figure 8. Typical hardness distribution in weld region.

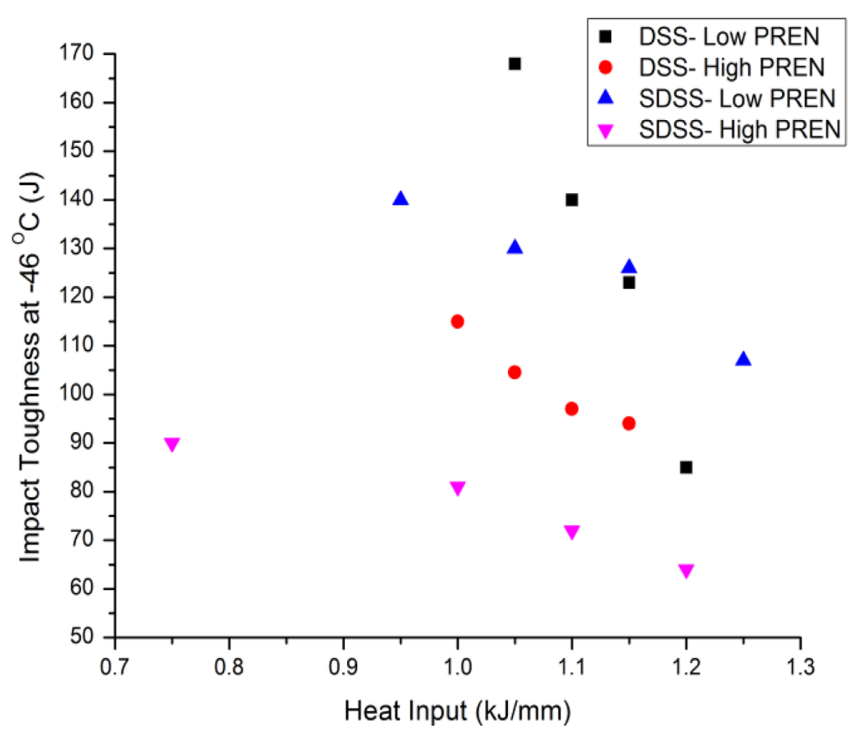

Figure 9. Variation of impact toughness $\left(\right.$ at $\left.-46{ }^{\circ} \mathrm{C}\right)$ with heat input.

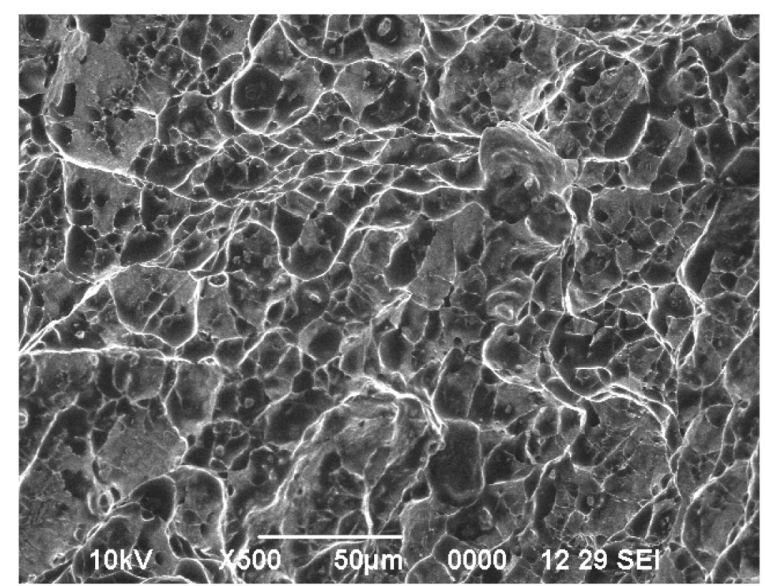

(a)
SDSS base material has higher toughness values because of high content of $\mathrm{Cr}$ and Mo alloying elements. From literature, we noted that these higher alloying elements may promote formation of intermetallic phases at high temperatures. Hence, it is very important to control weld parameters in order to avoid intermetallic phases formation as SDSS is more prone to sigma and secondary austenite phase formation than DSS. Intermetallic phases will drastically reduce toughness value of the weldments.

Figure 10 shows fractography images of the joints taken on SEM. It can be seen that both materials showed signs of ductile fracture as dimples were obserevd. Fractography for DSS/ SDSS specimen showed more dimples and small average dimple size which suggests ductile mode of fracture was dominant in fractured welded samples [11]. Also, we observed some cleavages (i.e. flat surafces) in both specimens which indicates brittle phase because of intermetallic components.

Impact value will vary from weld centre line to the base metal. Fusion line, HAZ and weld will have different impact toughness properties. In order to understand the impact toughness values through weld line, $\mathrm{V}$-notch were made at weld metal, fusion line, $2 \mathrm{~mm}$ from fusion line and $5 \mathrm{~mm}$ from fusion line. Figure 11 shows impact toughness variation on weld centre, fusion line, $2 \mathrm{~mm}$ from FL and $5 \mathrm{~mm}$ from FL. Impact toughness value of fusion line was observed as low when compare to weld centre, FL +2 and FL +5 . It is obvious that grain growth end at fusion line and it becomes solidification line during welding, which may reduce impact value. At V-notch positions $2 \mathrm{~mm}$ and $5 \mathrm{~mm}$ from fusion line, we observed higher toughness value as it is nothing but base metal with little exposure to temperature gradients.

Higher nitrogen content in shielding and backing gas mixture has assisted to improve impact toughness value on both DSS and SDSS materials. This could be due to the fact that nitrogen will assist to obtain austenite and ferrite phase balance. Increase in nitrogen content will broaden separation between two dislocation planes, which restricts the dislocations to their own slip planes [9].

An increase in interpass temperature had a negative effect on impact toughness due to prolonged exposure to sensitive temperature range and slow cooling rate, which promotes

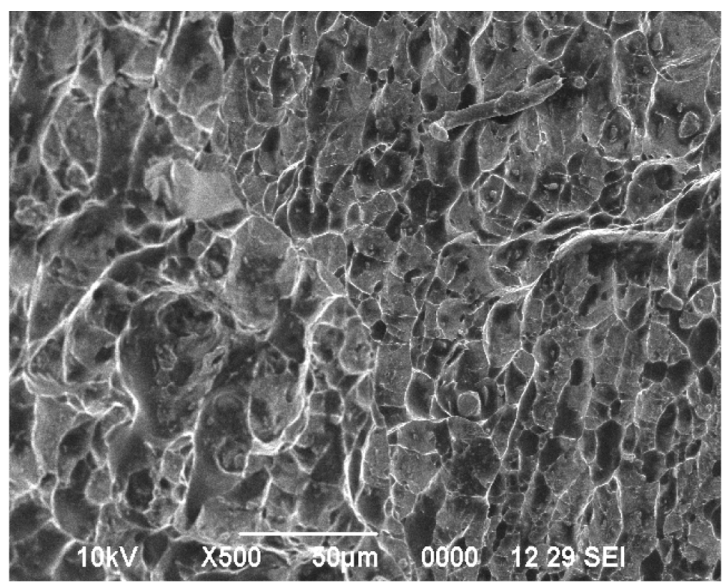

(b)

Figure 10. SEM images of fractured samples during Charpy V-notch impact test (a) DSS, (b) SDSS. 


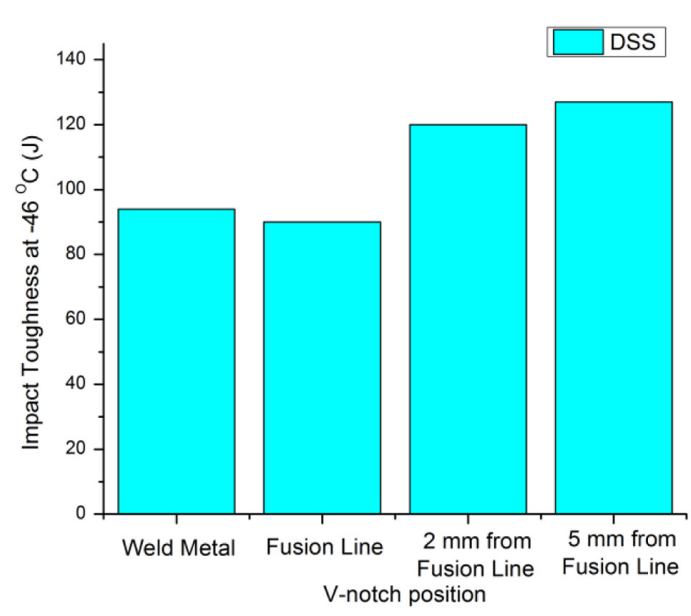

Figure 11. Impact toughness values at different V-notch positions.

formation of sigma phase in weld zone. This brittle sigma phase is the main cause for reduction of impact toughness values in weldments and HAZ.

\section{Conclusions}

- GTAW of DSS and SDSS was successfully done and effect of welding parameters on mechanical properties were studied. For DSS, heat input of $1.0-1.1 \mathrm{~kJ} / \mathrm{mm}$ and for SDSS, heat input of $0.75-1.05 \mathrm{~kJ} / \mathrm{mm}$ were found to give excellent mechanical properties.

- Tensile strength of all weldments was $5-10 \%$ higher than that of base material. The highest strength values were $805 \mathrm{MPa}$ for DSS and $862 \mathrm{MPa}$ for SDSS weldments. There was a decrease in strength of weldments with increase in heat input due to grain coarsening and less ferrite content.

- Hardness values decreased with higher heat input for both DSS and SDSS. At weld root area, high hardness values were observed due to presence of hard and brittle intermetallic phases and varying weld thermal cycles.

- Impact toughness decreased with increase in heat input because of intermetallic phase formation, secondary austenite formation and increase in grain size at higher heat input. The highest toughness values were $168 \mathrm{~J}$ for DSS and $140 \mathrm{~J}$ for SDSS at $-46^{\circ} \mathrm{C}$. There was a significant loss of toughness in SDSS samples as they are more prone to intermetallic/secondary phases formation.

- Higher nitrogen contents in shielding and purging gas (i.e. $\operatorname{Ar}+5 \% \mathrm{~N}$ ) slightly improved tensile strength and impact toughness due to strengthening of austenite phase than $\mathrm{Ar}+2 \% \mathrm{~N}$ gas mixture but $\mathrm{Ar}+2 \% \mathrm{~N}$ has also given equally comparable results.

- An increase in interpass temperature from $120^{\circ} \mathrm{C}$ to $160{ }^{\circ} \mathrm{C}$ reduced strength and toughness value due to coarse grain formation and sigma phase formation.

- Based on the experiments and test results, improved mechanical properties were obtained with low heat input, low inter-pass temperature and $\mathrm{Ar}+5 \% \mathrm{~N}$ shielding/back

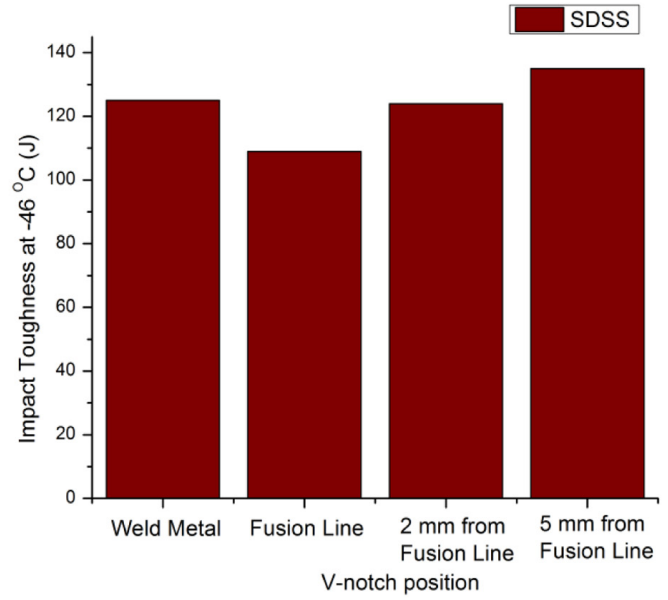

purging gas. Due to higher alloying elements in SDSS, welding variables shall be properly controlled in order to avoid intermetallic and secondary austenite phase formation. Following weld parameters were recommended to obtain better mechanical properties of DSS and SDSS material. (a) Heat input $(0.75-1.1 \mathrm{~kJ} / \mathrm{mm})$, (b) interpass temperature $\left(<120^{\circ} \mathrm{C}\right)$, (c) stringer bead technique, (d) shielding/purging gas $-\mathrm{Ar}+2 \% \mathrm{~N}$.

\section{References}

1. I. Alvarez-Armas, S. Degallaix-Moreuil (Eds.), Duplex stainless steels, John Wiley \& Sons, New Jersey, USA, 2013.

2. M. Mohammed Asif, K.A. Shrikrishna, P. Sathiya, S. Goel, The impact of heat input on the strength, toughness, microhardness, microstructure and corrosion aspects of friction welded duplex stainless steel joints, J. Manuf. Process. 18 (2015) 92-106.

3. J. Charles, Duplex stainless steels - a review after DSS'07 held in Grado, Steel Research International 79 (2008) 455-465.

4. R. Cervo, P. Ferro, A. Tiziani, Annealing temperature effects on super duplex stainless steel UNS s32750 welded joints. I: Microstructure and partitioning of elements, J. Mater. Sci. 45 (2010) 4369-4377.

5. A.V. Jebaraj, L. Ajaykumar, Influence of microstructural changes on impact toughness of weldment and base metal of duplex stainless steel AISI 2205 for low temperature applications, Procedia Eng. 64 (2013) 456-466.

6. G. Fargas, M. Anglada, A. Mateo, Effect of the annealing temperature on the mechanical properties, formability and corrosion resistance of hot-rolled duplex stainless steel, J. Mater. Process. Technol. 209 (2009) 1770-1782.

7. S. Topolska, J. Łabanowski, Effect of microstructure on impact toughness of duplex and superduplex stainless steels, J. Achieve. Mater. Manuf. Eng. 36 (2009) 142-149.

8. E. Taban, E. Kaluc, T.S. Aykan, Effect of the purging gas on properties of 304H GTA welds, Welding Journal 93 (2014) $124 \mathrm{~s}-130 \mathrm{~s}$

9. K. Migiakis, G.D. Papadimitriou, Effect of nitrogen and nickel on the microstructure and mechanical properties of plasma 
welded UNS S32760 super-duplex stainless steels, J. Mater. Sci. 44 (2009) 6372-6383.

10. M. Martins, L.C. Casteletti, Effect of heat treatment on the mechanical properties of ASTM A 890 Gr6A super duplex stainless steel, J. ASTM Int. 2 (2005) 1-14.
11. S.S.M. Tavares, J.M. Pardal, L.D. Lima, I.N. Bastos, A.M. Nascimento, J.A. de Souza, Characterization of microstructure, chemical composition, corrosion resistance and toughness of a multipass weld joint of super duplex stainless steel UNS S32750, Mater. Charact. 58 (2007) 610-616.

Cite this article as: Paulraj P \& Garg R: Effect of welding parameters on mechanical properties of GTAW of UNS S31803 and UNS S32750 weldments. Manufacturing Rev. 2015, 2, 29. 